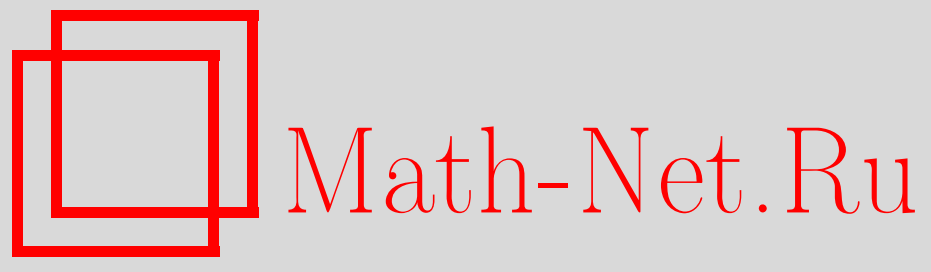

А. Г. Сергеев, О юбилейной научной сессии, посвященной

75-летию

Математического института им. В. А. Стеклова, УMH, 2009, том 64, выпуск 4, 191-194

DOI: https://doi.org/10.4213/rm9309

Использование Общероссийского математического портала Math-Net.Ru подразумевает, что вы прочитали и согласны с пользовательским соглашением http://www . mathnet.ru/rus/agreement

Параметры загрузки:

IP : 54.157 .27 .8

26 апреля 2023 г., 13:06:35

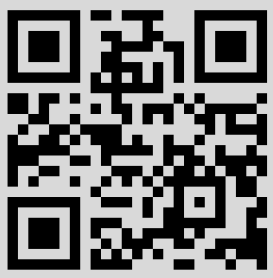




\section{О юбилейной научной сессии, посвященной 75-летию Математического института им. В. А. Стеклова}

\section{А. Г. Сергеев}

В 2009 г. Математическому институту им. В. А. Стеклова Российской академии наук исполнилось 75 лет. Официальным “днем рождения" Института считается 28 апреля 1934 г., когда Академия наук СССР приняла решение о разделении Физико-математического института им. В. А. Стеклова на два самостоятельных учреждения Математический институт им. В. А. Стеклова и Физический институт им. П. Н. Лебедева.

Юбилей Института - заметное событие в научной жизни страны. У многих сотрудников еще живы в памяти воспоминания о праздновании 50-летнего юбилея МИАН в 1984 г., когда в Москве и Ленинграде прошла уникальная Международная конференция с участием выдающихся отечественных и иностранных ученых: Н. Н. Боголюбова, Л. С. Понтрягина, М. Атьи, Ж.-Л. Лионса, Ю. Мозера, Ф. Хирцебруха. Организаторам юбилейных торжеств 2009 г. хотелось, чтобы и это празднование сохранилось в памяти участников на долгие годы. Кроме того, было важно наглядно продемонстрировать, что Институт с уверенностью "смотрит в будущее”, сохраняя и развивая славные традиции советско-российской математической школы.

Какой же формат выбрать для юбилейной научной сессии? Было ясно, во-первых, что она должна пройти, как и 25 лет назад, в Москве и Санкт-Петербурге. МИАН и ПОМИ выросли из одного корня и вместе определяют по-прежнему “лицо" отечественной математики.

Другая идея - юбилейная конференция не должна превратиться в "корпоративный праздник для посвященных", она должна стать событием для всей научной общественности, праздником для всех, кто интересуется математикой.

Еще одно соображение. В годы перестройки многие из сотрудников Института волею судеб покинули его, получив позиции в зарубежных университетах. Мы считали, что юбилей Института - это и их праздник.

На базе таких соображений и сформировалась концепция проведения юбилейной научной сессии, которую можно выразить в виде следующих основных принципов:

1. Небольшое количество приглашенных докладов, представляющих два поколения наших математиков и зарубежных гостей по формуле: $5+5+5$.

2. Один из дней конференции отводится математике для школьников и "круглому столу", посвященному обсуждению общественно значимых математических проблем (таких как образование, "утечка мозгов" за границу и т. д.).

3. Включение в программу конференции выступлений внештатных сотрудников Института, работающих в настоящее время за границей.

Теперь более подробно о программе юбилейной научной сессии в том виде, в каком удалось ее реализовать.

Юбилейная сессия открылась конференцией внештатных сотрудников МИАН, проходившей в Математическом институте 5-6 июня 2009 г. На нее были приглашены 
сотрудники Института, работающие за рубежом (к сожалению, часть из них не смогли приехать по уважительным причинам, а другие, похоже, не получили сообщение о конференции из-за проблем с электронной почтой, связанных с "антиспамовыми" программами). Доклады, представленные на конференции, отличались высоким уровнем и вызвали большой интерес. Их видеозаписи (так же как и видеоверсии остальных докладов, представленных на юбилейной научной сессии) можно найти на веб-странице по адресу: http://75.mi.ras.ru. Поэтому ограничимся здесь перечислением авторов и названий.

\section{5 июня:}

1. Б. А. Дуьровин, “Критическое поведение в нелинейных гамильтоновых уравнениях в частных производных и трансценденты Пенлеве".

2. С. Б. Куксин, “Диссипативные возмущения интегрируемых уравнений в частных производных".

3. Ю. С. ЛЕдяЕв, "Разрывные синтезы в нелинейных управляемых системах и задачи стабилизации".

\section{6 июня:}

4. Р. И. Григорчук, "Развитие теории аменабельных групп за 80 лет".

5. А. Н. ДрАнишников, "К гипотезе Громова о макроскопической размерности".

6. В. В. Никулин, "О классификации арифметических групп, порожденных отражениями, в пространствах Лобачевского”.

Вечером 5 июня состоялось торжественное собрание сотрудников МИАН, посвященное 75-летию Института. Его открыл директор МИАН В.В. Козлов. Своими воспоминаниями об истории Института поделились наши выдающиеся математики В. С. Владимиров, С. М. Никольский, Ю.В.Прохоров, И. Р. Шафаревич. С приветствием от Академии криптографии выступил ее вице-президент В.Н. Сачков. Поздравили Институт с юбилеем его сотрудники С. Б. Куксин и С. Ю. Немировский. Украшением заседания стал слайд-фильм (демонстрировавшийся на экране во время заседания), благодаря которому в собрании приняли "незримое участие" те, кто не мог на нем присутствовать лично.

Торжественное открытие юбилейной научной конференции состоялось 8 июня в Президентском зале здания Президиума РАН на площади Гагарина. K участникам и гостям конференции (присутствовало около 300 человек) обратился президент Российской академии наук Ю. С. Осипов, выступивший с докладом, посвященным юбилею Института. Докладчик напомнил слушателям о том, что МИАН является для него "родным домом": Ю. С. Осипов возглавлял Институт в период с 1993 по 2004 г. и по сей день остается его главным научным сотрудником. Именно в то время, когда он был директором МИАН, было построено новое здание Института, составляющее предмет гордости его сотрудников.

С приветствиями в адрес Института обратились министр науки и образования Российской Федерации А. А. Фурсенко, президент Международного союза математиков Л. Ловас, президент Европейского математического общества А. Лаптев, директор Физического института им. П. Н. Лебедева Г. А. Месяц, директор Санкт-Петербургского отделения Математического института С. В. Кисляков, ректор Московского государственного университета В. А. Садовничий, директор Института математики Сибирского отделения РАН Ю. Л. Ершов.

С докладом о Математическом институте им. В. А. Стеклова выступил директор МИАН В. В. Козлов. В его выступлении была проанализирована деятельность Института на протяжении всей его истории - с момента возникновения и до нынешних дней. Большое внимание было уделено истокам отечественной математической школы, достойным представителем которой является МИАН. 
Научная программа первого дня конференции открылась выступлением выдающегося французского математика ЖК.-П. Серра “Зависимость от $p$ числа решений по модулю $p$ семейства полиномиальных уравнений" и продолжилась докладами президента Международного союза математиков, венгерского ученого Л. Ловаса “Экстремальные графы, алгебры графов и категории" и заведующего отделом дифференциальных уравнений МИАН Д. В. Аносова "Локальная максимальность гиперболических множеств".

Завершился первый день праздничным фуршетом, на котором с приветствиями в адрес Математического института обратились председатель Российского фонда фундаментальных исследований В.Я. Панченко, директор Института математики и механики Уральского отделения РАН В. И. Бердышев, директор Вычислительного центра РАН Ю.Г. Евтушенко, директор Института математики Польской академии наук С. Янечко, представитель Института математики и информатики Болгарской академии наук Й. Давидов и многие другие.

На следующий день (9 июня) конференция продолжила свою работу в здании МИАН на улице Губкина. Вся первая половина этого дня была отведена Фестивалю художественной математики для школьников, которые заполнили вестибюль и конференц-зал Института (некоторые приходили целыми классами). Открыл Фестиваль заместитель главного редактора журнала "Квант", ведущий научный сотрудник МИАН Н. П. Долбилин. Он предоставил слово замечательному японскому популяризатору математики Дж. Акияме, который назвал свое выступление "Математика, которую я люблю". Собственно, то, что происходило затем, даже трудно назвать "выступлением" - скорее, это была игра в математику с ее молодыми и взрослыми любителями, сидевшими в зале и стоявшими в проходах, поскольку "сидячих" мест на всех желающих не хватило. В течение полутора часов Дж. Акияма (вместе со своими ассистентками) держал в напряжении зал: слушатели боялись пропустить хоть что-то из его слов, большая часть которых не нуждалась в переводе, поскольку излагалась на универсальном языке математики. Остальное живо переводилось студентом мехмата А. Фонаревым. В перерывах со столов, выставленных в фойе, моментально сметались как книги самого Дж. Акиямы, так и другие популярные математические издания. Фестиваль продолжился выступлением научного сотрудника МИАН Н.Н. Андреева, который продемонстрировал присутствующим свои "Математические этюды" - математические анимации, уже получившие известность как у нас в стране, так и за рубежом. Нет сомнения в том, что прошедший Фестиваль художественной математики оказался достойным своего амбициозного названия.

Во второй половине дня 9 июня состоялся Круглый стол на тему "Математика и общество". На него были приглашены представители различных математических заведений Москвы и Петербурга, а также журналисты, пишущие о проблемах науки. Большая часть выступлений касалась образовательной реформы в стране, вызывающей столь неоднозначную реакцию в нашем обществе. О проблемах реформы говорили главный научный сотрудник МИАН В. А. Васильев, директор Московского центра непрерывного математического образования И. В. Ященко, профессор Высшей школы экономики Д. С. Шмерлинг, заведующий отделом логики МИАН С. И. Адян. Академик В. С. Владимиров напомнил присутствующим о трудностях, сопровождавших реформу школьного образования в СССР, профессор Дж. Акияма поделился опытом японских коллег в этом направлении. Большой интерес вызвали выступления наших петербургских коллег А. М. Вершика и О. Я. Виро. Итог дискуссии подвел директор МИАН В. В. Козлов.

Заключительный день московской части конференции (10 июня) был отведен для докладов молодых математиков МИАН. Приведем названия их докладов:

1. М. Э. КАзАРян, "Неассоциативная схема Гильберта и многочлены Тома".

2. А. Г. Кузнецов, "Производные категории когерентных пучков и рациональность алгебраических многообразий".

3. С. Ю. НЕмиРовСКий, "Причинность и контактная геометрия". 
Все выступления были встречены с большим интересом сотрудниками МИАН и гостями конференции.

В тот же день участники конференции выехали в Санкт-Петербург, где конференция продолжила свою работу.

Питерскую часть конференции, проходившую в здании ПОМИ на Фонтанке, открыл 11 июня директор Санкт-Петербургского отделения Математического института С. В. Кисляков. С приветствием к участникам обратился заместитель директора МИАН А. Г. Сергеев. Научная программа дня включала в себя следующие выступления:

1. О. Я. Виро, "Относительные гомологии Хованова".

2. Л. Д. ФАДДЕЕВ, "История квантовых групп".

3. С. В. ИвАнов, "Граничная жесткость и минимальные заполнения".

Послеобеденное время было отведено "художественной математике" в исполнении Дж. Акиямы и Н.Н. Андреева.

Во второй день питерской части (12 июня) состоялись выступления:

4. Ж.-П. КАХАН, "Числа вращения и ряды Фурье".

5. С. П. Новиков, "Новая дискретизация комплексного анализа".

6. Н. В. Дуров, "Классифицирующие вектоиды и обобщения операд".

На этом научная программа питерской части, а с нею и вся программа юбилейной научной сессии, посвященной 75-летию МИАН, была завершена.

Стоит отметить, что, помимо научной составляющей, юбилейные торжества включали в себя и различные культурные мероприятия. В Москве для гостей конференции была организована экскурсия в храм Христа Спасителя с подъемом на смотровую площадку храма. В Санкт-Петербурге состоялась незабываемая ночная прогулка на теплоходе, участники которой стали свидетелями разводки мостов на Неве.

К юбилею Института был выпущен уникальный словарь-справочник (составители Э. П. Зимин, С.В. Кисляков, Г. С. Монахтина, В.П. Павлов), содержащий краткие биографии членов Российской академии наук, работавших в МИАН. Подготовлен красочный буклет, отчеканены памятная медаль и значок Института. Отметим также публикации в газете "Поиск" и других средствах массовой информации, посвященные МИАН.

В заключение хочу поблагодарить всех сотрудников МИАН и ПОМИ, аспирантов и студентов, принявших участие в подготовке и проведении юбилейной научной сессии. Ваши усилия не пропали даром - юбилейные торжества прошли на высоком уровне и, мы уверены, надолго запомнятся их участникам. 